\title{
Dried Skeletonema costatum in Feed Formulation for the Growth of Vaname Shrimp (Litopenaeus vannamei)
}

\author{
Dewi Putri Lestari ${ }^{1^{*}}$, Arning W. Ekawati ${ }^{2}$ Maftuch $^{2}$ \\ ${ }^{1}$ Graduate Program, Faculty of Fisheries and Marine Sciences, University of Brawijaya, Malang, Indonesia \\ ${ }^{2}$ Faculty of Fisheries and Marine Sciences, University of Brawijaya, Malang, Indonesia
}

\begin{abstract}
The aim of this study was to determine the effect and the best dosage used by the Skeletonema costatum in feed formulation on the growth of Vaname shrimp. This experiment used Completely Randomized Design (CRD) with four treatments and three replications. Treatment was given by using dried S. costatum in feed formula (iso protein $37 \%$ and iso energy $3.6 \mathrm{kkal} / \mathrm{g}$ feed). Feed treatment was the substitution of fish meal protein $A=0 \%, B=2.5 \%, C=5 \%$ and $D=$ 7.5\% with dried S. costatum protein. The observed parameters include Survival Rate (SR), Survival Growth Rate (SGR), Feed Efficiency Ratio (FER), and Protein Efficiency Ratio (PER). The results showed that the use of dried S. costatum in feeding are effective in increasing the specific growth rate, feed efficiency ratio and the ratio of protein efficiency than controls. The best dosage in feeding formula is ranged from $4.39 \%$ to $4.75 \%$.
\end{abstract}

Keywords: feeding formula, Skeletonema costatum, Vaname Shrimp

\section{INTRODUCTION}

Vaname shrimp (Litopenaeus vannamei Boone) is one of the leading commodities of Indonesian fishing industry. This shrimp has high productivity in intensive pond thus many farmers cultivate its as the substitute of tiger shrimp. Vaname shrimp is widely known for its advantages of faster ability in growing than Black Tiger and Stylirostris shrimp. Vaname shrimps also can be stocked at high densities, resistant to wide range of salinity, need lower protein and resistance to diseases $[1,2,3]$.

Diatoms contain essential nutrients and also have an appropriate size as feed for Vaname shrimp. One of a diatoms which commonly used for feed is Skeletonema costatum (Greville) Cleve. The use of diatoms as a natural feed for Vaname shrimp can accelerate its growth in larval stadia. Skeletonema costatum is used as a supplementary food for basic nutrition in cultured Artemia, shrimp larvae and shellfish spat. Nutritional content of $S$. costatum has been widely studied, which is consisted of $31 \%$ protein, $21.5 \%$ carbohydrate and $1.3 \%$ total fat. In addition, $S$. costatum also contain fatty acid composition, free amino acids, ß-1, 3 glucan and cell wall polysaccharides $[4,5,6]$.

However, the use of diatom $S$. costatum in dry form has not been widely used. The glucan

\footnotetext{
* Correspondence author:

Dewi Putri Lestari

Email : dewiputrilestari1@gmail.com

Address : Faculty of Fisheries and Marine Sciences, University of Brawijaya, Jl. Veteran, Malang, 65145
}

which also found in diatom acts as an immunostimulant which will enhance the body's resistance of the shrimp. Thus the aim of adding dried S. costatum on Vaname shrimp's feed formulations are to enhance the growth and productivity by observing the parameter which measures the growth rate of shrimp, e.g. survival, specific growth rate, feed efficiency ratio, and protein efficiency ratio. Observed parameter choosen because related to the feed utilization and growth of the shrimp. This study aimed to determine the best used dose of dried $S$. costatum in the feed formulation on the growth of Vaname shrimp.

\section{MATERIALS AND METHODS}

\section{Preparation of Dried S. costatum}

Skeletonema costatum was obtained from Center of Brackish Aquaculture Situbondo, from seawater which were purified repeatedly with pure subsequently cultured in a laboratory-scale stage, semi mass scale and mass scale. Furthermore, $S$. costatum were dried using an oven in temperature $60^{\circ} \mathrm{C}$ for 24 hours. The dried $S$. costatum analyzed proximately for its drying content using the oven method and its crude protein concentration using the micro kjedahl.

\section{Preparation of feed}

Before determining the formula, other feed's constituent material (fish meal, shrimp meal, soybean flour, tapioca flour, fish oil, vitamin, min mix and $(M C$ ) had been prepared and analyzed the proximate data according to AOAC [7]. 
Table 1. Composition of experiment feed ingredients for vaname shrimp (Litopenaeus vannamei)

\begin{tabular}{|c|c|c|c|c|c|c|c|}
\hline Ingredient & $\begin{array}{c}\text { Dried } \\
\text { Content } \\
(\%)^{*}\end{array}$ & $\begin{array}{l}\text { Protein } \\
(\%)^{*}\end{array}$ & $\begin{array}{l}\text { Fat } \\
(\%)^{*}\end{array}$ & $\begin{array}{c}\text { Ash Content } \\
(\%)^{*}\end{array}$ & $\begin{array}{c}\text { Rugged fiber } \\
(\%)^{*}\end{array}$ & BETN** & $\begin{array}{c}\text { Energy } \\
(\mathrm{kkal} / \mathrm{gr})^{* * *}\end{array}$ \\
\hline Fish meal* & 92.19 & 56.86 & 6.12 & 28.7 & 4.91 & 3.41 & 296.16 \\
\hline Shrimp meal* & 92.20 & 50.36 & 4.33 & 1.33 & 8.94 & 35.04 & 380.55 \\
\hline S. costatum meal* & 87.38 & 24.70 & 2.22 & 55.55 & 1.04 & 16.49 & 184.74 \\
\hline Soybean flour* & 91.74 & 45.65 & 0.14 & 7.90 & 4.23 & 42.08 & 352.18 \\
\hline Tapioca flour* & 87.19 & 0.09 & 0.02 & 0.06 & 1.01 & 98.82 & 398.82 \\
\hline
\end{tabular}

Description :

$\begin{array}{ll}* & : \\ * * & : \\ * * * & :\end{array}$

Result analysis of Laboratory Nutrition and Feed, Faculty of Animal Husbandry, University of Brawijaya BETN $=100-$ Protein - Fat - Ash content - Rugged fiber Energy $=(4 \times \%$ Protein $)+(9 \times \%$ Fat $)+(4 \times \%$ BETN $)$

Table 2. Experiment feed formula of Vaname shrimp (Litopenaeus vannamei)

\begin{tabular}{lcccc}
\hline \multirow{2}{*}{ Ingredient (\%) } & \multicolumn{4}{c}{ Treatment Dose } \\
\cline { 2 - 5 } & A & B & C & D \\
\hline Fish meal & 24.73 & 23.10 & 21.47 & 19.85 \\
Shrimp meal & 26.45 & 26.45 & 26.45 & 26.45 \\
Soybean meal & 21.07 & 21.07 & 21.07 & 21.07 \\
S. costatum meal & - & 3.74 & 7.49 & 11.23 \\
Tapioca meal & 8.31 & 7.78 & 7.25 & 6.72 \\
Fish oil & 9 & 9 & 9 & 9 \\
Vit + Min Mix & 5 & 5 & 5 & 5 \\
CMC & 5.44 & 3.86 & 2.27 & 0.68 \\
\hline Total & $\mathbf{1 0 0}$ & $\mathbf{1 0 0}$ & $\mathbf{1 0 0}$ & $\mathbf{1 0 0}$ \\
\hline Description & & & &
\end{tabular}

\section{Description :}

$A=S$. costatum meal protein substitution on fish meal protein $0 \%$

$\mathrm{B}=\mathrm{S}$. costatum meal protein substitution on fish meal protein $2.5 \%$

$\mathrm{C}=\mathrm{S}$. costatum meal protein substitution on fish meal protein $5 \%$

$\mathrm{D}=\mathrm{S}$. costatum meal protein substitution on fish meal protein $7.5 \%$

Based on the proximate data of feed's constituent material (Table 1), the feed formulation is determined by worksheet method. Feed formulations based on the isoprotein $37 \%$ and isoenergi $3.6 \mathrm{kcal} . \mathrm{g}^{-1}$. The treatments were protein substitution of fish meal to $S$. costatum meal (Table 2). All the materials were weighed according to the formulation and mixed until it reached its homogeneity. Homogenate were molded and dried in an oven on the temperature of $30^{\circ} \mathrm{C}$ for 1 day. Feeds of Vaname shrimp were made in pellets form in $0.55 \mathrm{~mm}$ size.

\section{Biological Trials (In vivo)}

Biological test of feeding experiments on Vaname shrimp (Litopenaeus vannamei) were conducted for 30 days. Each treatment was repeated three times. Control diet without using $S$. costatum meal, compared with three feed formulas that use $S$. costatum meal as the independent variable. The four treatments of feed formulations observed to assess its effect on survival rate (SR), specific growth rate (SGR), feed efficiency ratio (FER), and protein efficiency ratio (PER), which is referred as dependent variable.
This study used Vaname shrimp (Litopenaeus vannamei) in juvenile stadia with weight $6.41 \pm 0.55 \mathrm{~g}$ per shrimp, derived from Center of Brackish Aquaculture Situbondo. The Vaname shrimps were maintained in an aquarium sized $45 \times 45 \times 45 \mathrm{~cm}^{3}$ volume of 71 liters filled with sea water and the range of the salinity for 33-34 ppt. The outer surface of aquarium was covered with black plastic to imitate the real habitat of the shrimps. The aeration was also included in the aquarium.

Shrimp was acclimatized in the experimental container for 7 days toward the environment and feed. The day before the study was conducted, the shrimp were not feeded and weighed it right after fasting to determine the initial weight. Shrimp were stocked with initial weights uniformly with density of 12 shrimp per aquarium. Feed trials were given as much as $10 \%$ of the biomass weight, 4 times daily; as much as $20 \%$ at $07.00,20 \%$ at $11.00,20 \%$ at 17.00 and $40 \%$ at 21.00 of the amount given per day. Shrimp were weighed every 10 days. Removal of remains feed were done every morning before feeding and the water replaced as much as 20 $30 \%$ of the total volume. 
Measurement of water quality during the study include temperature, DO (Dissolved oxygen), $\mathrm{pH}$ and salinity which was done every day in the morning and evening. Otherwise, amonial content was measured at the beginning and end of the study.

\section{Data analysis}

Data were analyzed using SPSS 21.0 version with one way ANOVA test. The analysis was used to examine the effect of treatment, continued to Least Significant Difference (LSD) test with Duncan test method. This test followed by the analysis of orthogonal polynomials to get the best treatment value.

\section{Survival Rate (SR)}

Survival of Vaname shrimp (L. vannamei) is calculated using the formula [8]:

$$
\mathrm{SR}=\frac{N t}{N o} x 100 \%
$$

Description:

$\mathrm{SR}=$ Survival Rate

$\mathrm{Nt}=$ Final number of shrimp

No = Initial number of shrimp

\section{Survival Growth Rate (SGR)}

Observations growth of vannamei shrimp (L.vannamei) was done by weighing once every 10 days. Specific growth rate [9] can be calculated using the formula:

$$
\mathrm{SGR}=\frac{\ln \overline{W t}-\ln \overline{W o}}{t} \times 100 \%
$$

Description:

$$
\begin{array}{ll}
\mathrm{SGR} & =\text { Survival Growth Rate (\%BW/day) } \\
\overline{W t} & =\text { Average final weight of individual (gram) } \\
\overline{W o} & =\text { Average initial weight of individual (gram) } \\
\mathrm{t} \quad & =\text { Time (days) }
\end{array}
$$

\section{Feed Efficiency Ratio (FER)}

Feed Efficiency Ratio was calculated by comparing the average final weight after reducing the initial average weight of shrimp compared to the amount of feed (dry weight of feed) using the formula [10]:

$$
F E R=\frac{\overline{(W t}-\overline{W o})}{F}
$$

Description:

FER = Feed Efficiency Ratio

$\mathrm{F} \quad=$ the amount of given feed (gram)

$\overline{W t}=$ Average final weight of individual (gram)

$\overline{W_{O}}=$ Average initial weight of individual (gram)

Protein Efficiency Ratio (PER)

Protein Efficiency Ratio [9] calculated using the formula:

$$
\text { PER }=\frac{(\overline{W t}-\overline{W o})}{(F x P f)}
$$

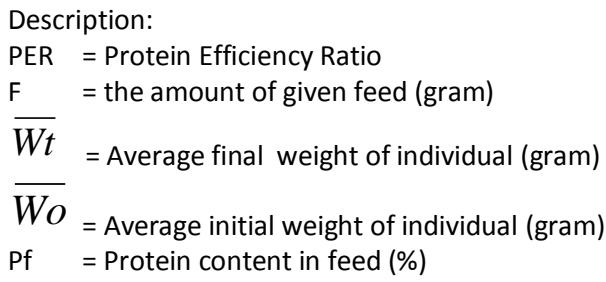

\section{RESULT AND DISCUSSION}

The Survival Rate (SR), Specific Growth Rate (SGR), Feed Efficiency Ratio (FER) and Protein Efficiency Ratio (PER) on Vaname shrimp can be seen in Table 3 . The results of one-way ANOVA showed that survival rate of Vaname shrimp is not significantly different between treatments $(P>0.05)$. It indicates that the use of $S$. costatum meal in the feed formulation does not cause a negative response to the survival rate of Vaname shrimp.

Factors affecting survival rate are abiotic factors such as the adaptation ability to the environment, human handling, stocking density, competitors, age and the presence of predators. High stocking density would result lower survival due to cannibalism. The range of the water quality values showed in Table 4.

Table 3. Value parameters each treatment

\begin{tabular}{lcccc}
\hline \multirow{2}{*}{ Parameters } & \multicolumn{4}{c}{ Treatment } \\
\cline { 2 - 5 } & A & B & C & D \\
\hline SR (\%) & $77.78 \pm 4.81^{\mathrm{a}}$ & $86.11 \pm 4.82^{\mathrm{a}}$ & $88.89 \pm 4.82^{\mathrm{a}}$ & $88.89 \pm 4.82^{\mathrm{a}}$ \\
SGR (\%BW.day ${ }^{-1}$ ) & $0.71 \pm 0.01^{\mathrm{a}}$ & $1.09 \pm 0.01^{\mathrm{c}}$ & $1.21 \pm 0.05^{\mathrm{d}}$ & $0.93 \pm 0.01^{\mathrm{b}}$ \\
FER (\%) & $8.22 \pm 0.35^{\mathrm{a}}$ & $12.88 \pm 0.26^{\mathrm{c}}$ & $14.74 \pm 0.76^{\mathrm{d}}$ & $11.09 \pm 0.01^{\mathrm{b}}$ \\
PER & $0.22 \pm 0.01^{\mathrm{a}}$ & $0.34 \pm 0.01^{\mathrm{c}}$ & $0.40 \pm 0.02^{\mathrm{d}}$ & $0.30 \pm 0.00^{\mathrm{b}}$ \\
\hline
\end{tabular}


Table 4. Water Quality of Vaname shrimp's Aquaculture during the study

\begin{tabular}{|c|c|c|c|c|c|}
\hline \multirow[t]{2}{*}{ Treatment } & \multicolumn{5}{|c|}{ Water Quality Paramaters } \\
\hline & pH & Temperature $\left({ }^{\circ} \mathrm{C}\right)$ & $\mathrm{DO}\left(\mathrm{mgL}^{-1}\right)$ & Salinity (ppt) & Ammonia $\left(\mathrm{mgl}^{-1}\right)$ \\
\hline $\mathrm{A}(0.0 \%)$ & $7.0-7.1$ & $30.00-31.44$ & $7.01-7.23$ & $33-34$ & $0.008-0.012$ \\
\hline $\mathrm{B}(2.5 \%)$ & $7.0-7.1$ & $30.10-31.32$ & $7.09-7.30$ & $33-34$ & $0.004-0.009$ \\
\hline$C(5.0 \%)$ & $7.0-7.1$ & $30.06-31.28$ & $7.11-7.25$ & $33-34$ & $0.001-0.007$ \\
\hline $\mathrm{D}(7.5 \%)$ & $7.0-7.1$ & $30.11-31.31$ & $7.06-7.20$ & $33-34$ & $0.001-0.018$ \\
\hline
\end{tabular}

Table 5. Water Quality References

\begin{tabular}{lcc}
\hline \multicolumn{1}{c}{ Parameters } & \multicolumn{2}{c}{ Water Quality Value } \\
\cline { 2 - 3 } & Study & References \\
\hline $\mathrm{pH}$ & $7.0-7.1$ & $6.8-8.7[15]$ \\
Temperature $\left({ }^{0} \mathrm{C}\right)$ & $30.00-31.44$ & $27-32[16]$ \\
DO $\left(\mathrm{mgL}^{-1}\right)$ & $7.01-7.30$ & $>3[16]$ \\
Salinity $(\mathrm{ppt})$ & $33-34$ & $33-35[17]$ \\
ammonia $\left(\mathrm{mgL}^{-1}\right)$ & $0.001-0.018$ & $>0.01[18]$ \\
\hline
\end{tabular}

Based on statistical analysis the water quality does not significantly affect the value of each treatment. The values of the parameters of water quality during the maintenance are in the normal range, accordance with other studies in Table 5.

Other factors that may increase the survival rate during the culture is Vaname shrimp's feed quality and feeding level so that the feed requirements can be met without any competition. Frequency of feeding behavior of vaname shrimp was also noted by de Lima et al. [11] indicating that feeding can affect the activity of shrimp itself. In the natural ecosystem, they generally actively feed at night, therefore the shrimp included in the group of nocturnal animals. This is supported by Kordi [12], feeding were given gradually, but more frequent. Thus the shrimp are not quickly satisfied and the shrimp's appetite is maintained.

The relationship between the amounts of substitution $S$. costatum meal protein to fish meal protein $(x)$ with survival $\left(y_{1}\right)$ showed in the equation:

$$
y_{1}=-0.333 x^{2}+3.944 x+77.91 ; R^{2}=0.57
$$

The highest known value is $88.98 \%$ survival rate with the best dose of $5.92 \%$ S. costatum meal to fish meal in the feed formula. According to Suwoyo and Mangampa [13], the increase of average weight of biota which is kept in line with the duration of maintenance can lead to the decrease of the individual specific growth rate. The difference in the growth rate could be due to the differences in the initial size and density of shrimp which were stocked, quality and quantity of feed, maintenance duration and cultivation containers which were used.

The relationship between the amounts of substitution $S$. costatum meal protein to fish meal protein $(x)$ with survival growth rate $\left(y_{2}\right)$, showed in the equation:

$$
y_{2}=-0.026 x^{2}+0.231 x+0.698 ; R^{2}=0.98
$$

The best value obtained from the treatment at a dose of $S$. costatum meal protein substitution by $4.44 \%$ in feed formula with a specific growth rate of $1.21 \%$ BW.day $^{-1}$. Feed efficiency ratio indicates that better utilization of feed and absorbed feed by the body increase the growth. The increasing feed efficiency values were caused by high nutrient that can be optimally utilized by the body.

The relationship between the amounts of substitution $S$. costatum meal protein to fish meal protein $(x)$ with feed efficiency ratio $\left(y_{3}\right)$ showed in the following equation:

$$
y_{3}=-0.008 x^{2}+0.076 x+0.215 ; R^{2}=0.95
$$

The best dosage is $4.39 \%$ with a value of feed efficiency ratio $14.47 \%$. The degree of protein efficiency ratio proteins is influenced by the quality of the feed. The higher the protein efficiency ratio values of feed protein quality the better it will be to increase the growth rate of shrimp. According to Buwono [14], protein quality of food is determined by the particular amino acid content of essential amino acids (arginine, histidine, isoleucine, leucine, lysine, methionine, phenylalanine, threonine, tryptophan and valine).

The relationship between the amounts of substitution $S$. costatum meal protein to fish meal protein $(x)$ with protein efficiency ratio $\left(\mathrm{y}_{4}\right)$ showed in the equation below. The best dose is $4.75 \%$ with a protein efficiency ratio 0.40 .

$$
y_{4}=-0.332 x^{2}+2.912 x+8.082 ; R^{2}=0.96
$$




\section{CONCLUSION}

The use of Skeletonema costatum meal protein to substitute fish meal protein in feed formula of Vaname shrimp affect the specific growth rate, feed efficiency ratio and protein efficiency ratio. The best dosage of $S$. costatum meal to increase the production of Vaname shrimp renged $4.39 \%-4.75 \%$ in feed formula.

\section{REFERENCES}

[1] Briggs, M., S.F. Smith, R. Subanghae, M. Phillips. 2004. Introduction and movement of Penaeus vannamei and $P$. stilyrostis in Asia and Pacific. FAO. 40p.

[2] Widodo, R.H., A.S. Dian. 2005. Shrimp vannamei: cultivation and market prospects disease resistance of white shrimp. Penebar Swadaya. Jakarta. 75p.

[3] Nur'aini, Y. L., H. Bambang, S. Subyakto, T. Gemi., 2007. Active surveilance of infectious myonecrosis virus (IMNV) in pond-cultured white shrimp (Litopenaeus vannamei) in East Java and Bali. Jurnal Perikanan UGM. IX (1). 25-31.

[4] Granum, E., S., Kirkvold, S. M. Myklestad. 2002. Cellular and extracellular production of carbohydrate and amino acid by the marine diatom Skeletonema costatum: diel variations and effects of $\mathrm{N}$ depletion. Mar. Ecol. Prog. Ser. 242. 83-94.

[5] Monkonsit, S., S. Powtongsook, P. Pavasant. 2011. Comparison between airlift photobioreactor and bubble column for Skeletonema costatum cultivation. Eng. J. 15(4). 53-64.

[6] Widiastuti, R., J. Hutabarat, V.E. Herawati. 2012. Effect of feeding different natural (Skeletonema costatum and Chaetoceros gracilis) to absolute biomass growth and nutrient content of local Artemia sp. J. Aquacult. Manage. Technol. 1 (1). 236-248.

[7] AOAC. 1995. Official methods of analysis $12^{\text {th }}$ Ed. Association of Official Analytical Chemists. Washington DC. 114p.

[8] Degani, G., D. Levanon. 1983. The influence of low density on food adaptation, cannibalism and growth of eels (Anqullia anquilla). Migal. Galilee Technological Center, Kiriat Shmona. Israel. 8p.

[9] De silva, S.S., T.A. Anderson. 1994. Fish nutrition in aquaculture. Chapman and Hall. London, UK. 319p.

[10] Li, M.H., E.H. Robinson, C.S. Tucker, B.B Manning, L. Khoo. 2009. Effect of dried algae Schizochytrium sp., a rich source of docosahexaenoic acid, on growth, fatty acid composition, and sensory quality of channel catfish Ictalurus punctatus. Aquaculture. 292. 232-236

[11] de Lima, P.P., C.S. Pontes, M. de Fátima Arruda. 2009. Activity pattern of the marine shrimp Litopenaeus vannamei (Boone 1931) in laboratory as a function of different feeding frequencies. Aquac. Res. 1-8.

[12] Kordi, M.G.H. 2010. Cultivation of catfish in tank Tarpaulins. Andi Publisher. Yogyakarta. $114 \mathrm{p}$.

[13] Suwoyo, H.S., M. Mangampa. 2010. Probiotics application with different concentration on maintenance Vaname Shrimp (Litopenaeus vannamei). Proceeding of Forum on Aquaculture Technology Inovation. 239-247.

[14] Buwono, I.D. 2000. Essential need of Amino Acid in fish Ransum. Kanisius. Yogyakarta. $56 p$.

[15] Ramanathan, N., P. Padmavathy, T. Francis, S. Athithian, N. Selvaranjitham. 2005. Manual on polyculture of tiger shrimp and carps in freshwater. Tamil Nadu Veterinary and Animal Science University, Fisheries College and Research Institute. Thothukudi. 1-161.

[16] Suprapto. 2005. Vannamei shrimp (Litopenaeus vannamei) cultivation techniques manual. CV Biotirta. Bandar Lampung. 25 p.

[17] Komaraeidjaja, W. 2003. Effect of application of microbial consortium of nitrifying the ammonia concentration (NH3) in the case of pond water: In Grinting village of Brebes. J. Tech. Env. P3TL-BPPT. 4(2). 6267.

[18] Taqwa, F.H., M. Fitrani, B.T. Esto. 2012. Performance of post-larval shrimp vaname (Litopenaeus vannamei) in various long period of adaptation with the addition of a low salinity decrease Sodium, Potassium, and Calcium. Proceedings of $2^{\text {nd }}$ SEMNAS on Fisheries and Marine Sciences Research. Faculty of Fisheries and Marine Sciences, Diponegoro University. Semarang. 3. 52-59. 